\title{
Conversion of Food Processing Waste to Bioenergy: Bangladesh Perspective
}

\author{
Mohammad Shaiful Alam Amin*, Musabbir Jahan Talukder, Rajarshi Roy Raju, \\ Maksudur R. Khan \\ Department of Chemical Engineering and Polymer Science, Shahjalal University of Science and \\ Technology, Sylhet 3114, Bangladesh.
}

Received September 19, 2018; Accepted October 10, 2018; Published October 15, 2018

\begin{abstract}
Microbial fuel cell (MFC) is an attractive renewable and sustainable technology to meet up the drastic energy crisis of the world through waste water treatment. This Bioelectrochemical system (BES) converts biomass spontaneously into electricity by the metabolic activity of microorganisms. Food processing industry generally discharges large volume of wastewater, which creates adverse financial and ecological impacts to the industry and environment. In this present contribution, electricity production from food processing industry wastewater that serves as substrates in MFCs was investigated. Dual chambered mediator-less MFC was designed and fabricated using locally available materials. Performance of the MFC was evaluated by measuring potential parameters, such as current generation, current density, change in $\mathrm{pH}$, and change in chemical oxygen demand at different operating conditions. Polarization experiments were conducted to find the maximum power density. Current generation increased with increasing sludge loading, and maximum results were recorded as $90 \mu \mathrm{A}$ with $9 \mathrm{~g}$ of sludge and optimum $\mathrm{pH}$ value 8 in the anode chamber. This study documented a maximum power density of $7.42 \mathrm{~mW} / \mathrm{m}^{2}$ with the corresponding current density of $25 \mathrm{~mA} / \mathrm{m}^{2}$.
\end{abstract}

Keywords: Microbial fuel cell; Food processing waste; Bio-electricity; Wastewater treatment; Chemical oxygen demand

\section{Introduction}

The severely increased demand of limited fossil energy sources (i.e., coal, petroleum, and natural gas); overwhelming climate changes due to air pollution; and the current escalation of energy cost considerably motivate the research toward searching new alternative energy production approaches. Like other countries due to the industrial revolution in Bangladesh, dependency and demand of electrical energy are increasing rapidly [1]. As a result, a variety of non-environmental friendly by-products such as greenhouse gases and hazardous solid wastes (e.g., radioactive wastes) are readily released to the environment. So, with this severe energy crisis, wastewater treatment is becoming another big issue for the present world [2-4]. Considering the socio-economic condition, we need both the industry and environment. 
There are around 700 small and large food manufacturing industries operating in Bangladesh, including homemade processing units. Among all, nearly 30 enterprises are processing fruits and vegetables [5]. Overall $20 \%$ of the labor forces of the country are engaged this sector [6]. In total, all food processing enterprises are the source of $2 \%$ of the gross domestic product (GDP) [7]. Now-a-days, this sector is growing rapidly and creating new opportunities in investment and export along with the modern equipped technology. However, the distinctive characteristics of agricultural and food industries make its effluent treatment process differ from the conventional municipal wastewater treatment process. Although the discharged wastewater are biodegradable and nontoxic, but it is rich in high suspended solids (SS), chemical and biochemical oxygen (COD and BOD) $[8,9]$. Therefore, these are industries are not only the source of opportunity; even so, there is a big concern on effluent treatment [10].

In this connection, microbial fuel cell (MFC) is a promising technology to meet the energy demand along with the food processing wastewater treatment [11-13]. MFC can utilize organic substances present in wastewater and be able to convert their chemical energy to electricity by using microorganisms as a catalyst [14-16]. For this benefit, interest on MFCs has massively grown in recent years. Number of researchers as well as the applications of this system are increasing, because of its simultaneous wastewater treatment and electricity generation $[17,18]$.

Design and construction of double chamber MFCs are widely studied for laboratory analysis. In this cell, organic matters of waste water are used as a fuel oxidized by bacteria and electrons are transferred to the anode. Electrons that pass along the circuit combine with electron acceptors. Thus, the biological electrochemical process and energy conversion are completed $[19,20]$. In this present study, food processing industry wastewater has been used as substrate; anaerobic sludge was used for inoculation and potassium permanganate solution as oxidant. Different experiments have been carried out in a locally fabricated MFC to find the optimum condition for current generation and COD removal. Polarization experiments were conducted to find the maximum power density.

\section{Materials and Methods}

\section{MFC Construction \& Inoculation}

Dual-chambered MFC was designed and fabricated in the laboratory using available local material. Two interconnected water bottle, $0.5 \mathrm{~L}$ of volume in each, was used as anode and cathode compartments. And each chamber was provided with sample port, wire point inputs (top), inlet and outlet ports (Figure 1). A Proton Exchange Membrane (PEM) membrane between two straight conduits was used to connect the two chambers. Two $1 \mathrm{~cm}$ long and $0.75 \mathrm{~cm}$ diameter plastic tubes were used for this purpose.

Food processing industry wastewater was collected from a renowned food processing industry in Sylhet, Bangladesh. Wastewater collected from the industry was used as the substrate in the anodic chamber of MFC. Sludge was collected from Drainage system of Surma Residential Area, Sylhet, Bangladesh. 


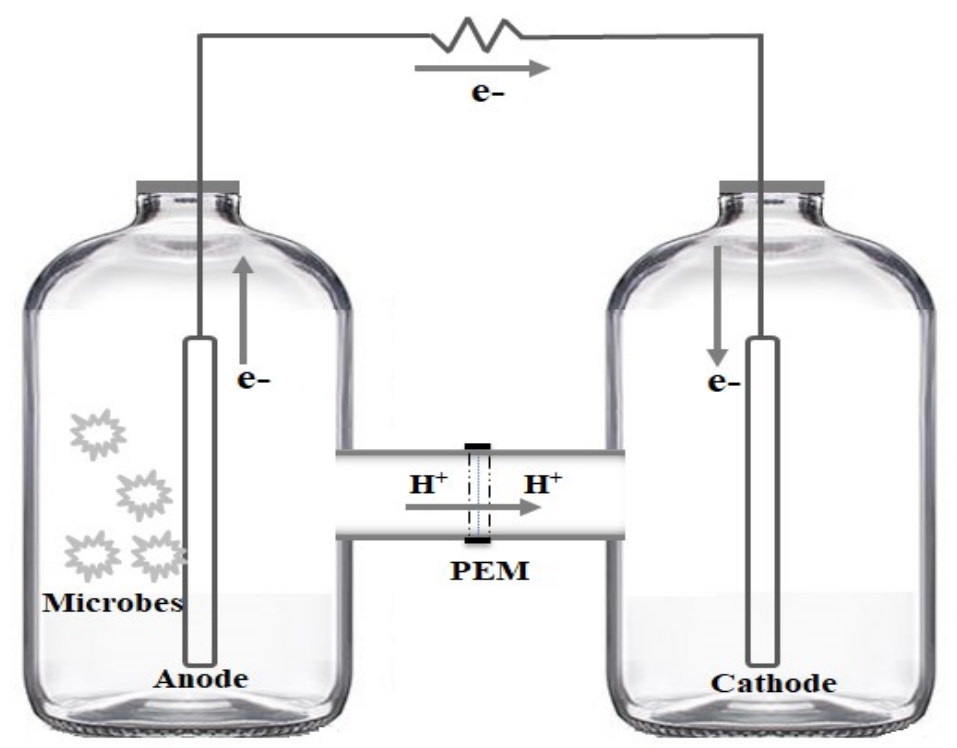

Figure 1. Schematic diagram of dual-chambered microbial fuel cell

Both the substrate and sludge were stored separately under anaerobic condition. This mixture was used as the original anodic inoculum. Before inoculation, the sludge was filtered through a sieve of $0.25 \mathrm{~mm}$ pore size to remove the impurities. The cells were operated in batch mode at room temperature $\left(28 \pm 2{ }^{\circ} \mathrm{C}\right)$ and at dark environment.

\section{MFC Operations}

The performance of MFC was investigated by conducting a series of experiments. Several experiments were conducted to find out the characteristics of the collected sample wastewater. The results can be summed up as $\mathrm{pH}: 3.1$, phosphate content: 6785 $\mathrm{mg} / \mathrm{L}$, sulphate content: $1105 \mathrm{mg} / \mathrm{L}$, nitrate: $15 \mathrm{mg} / \mathrm{L}$, glucose: $7.2 \mathrm{~g} / \mathrm{L}, \mathrm{TSS}: 453 \mathrm{mg} / \mathrm{L}$ and TDS: $22 \mathrm{mg} / \mathrm{L}$. Then the experiment was conducted to explore the effect of sludge loading in MFC on electricity generation. To do so, MFCs were operated with $1 \mathrm{~g}, 3 \mathrm{~g}, 6$ $\mathrm{g}$ and $9 \mathrm{~g}$ of sludge and one without sludge in the anode chamber. The changes of $\mathrm{pH}$ and voltage with time were noted. The subsequent experiments were conducted to scrutinize the effect of operating $\mathrm{pH}$. In these experiments, we increased the anode $\mathrm{pH}$ by using $\mathrm{NaOH}$. Three cells containing different influents $\mathrm{pH}$ of 7,8 and 9 were operated simultaneously. For each cell, $9 \mathrm{~g}$ of sludge was used to inoculate the anode chamber containing $350 \mathrm{ml}$ of waste water, while $200 \mathrm{ppm} \mathrm{KMnO}_{4}$ was used in the cathode at room temperature. As like the earlier experiments, electricity generation and voltage generation both in closed and open circuits were monitored. Polarization and power density curves were used to obtain the maximum power density by varying the external resistance using a resistor box. Voltage vs. current density and power density vs. current density data, \% COD removal, and effect of buffering were recorded at specified conditions which are demonstrated in the result and discussion section. Every experiment was conducted at least in duplicate at constant room temperature $\left(28 \pm 2{ }^{\circ} \mathrm{C}\right)$ and the average value was reported for all the data. 


\section{Analytics and Calculations}

A digital multimeter (FL-9205A, SHEN-HENXL Electronic Co. Ltd, China) was continuously operated to record the cell voltage and current, with a fixed resistance. Relation between the power and voltage, $P=I V$ (where, $I$ and $V$ represents current (A) and voltage (V), respectively), was used to calculate the cell power. Obtained power and current were divided by the anodic surface area $\left(\mathrm{m}^{2}\right)$ to observe the power and current. During the experiments, $\mathrm{pH}$ and chemical oxygen demand (COD) of the anode chamber were continuously monitored by using the standard procedures [21].

\section{Results and Discussion}

\section{Characterization of the Food Industry Wastewater}

Several methods were conducted to find out the characteristics of the collected sample wastewater of the well-known food processing industry in Bangladesh. The results can be summed up as $\mathrm{pH}$ : 3.1, phosphate content: $6785 \mathrm{mg} / \mathrm{L}$, Sulphate content: $1105 \mathrm{mg} / \mathrm{L}$ Nitrate: $15 \mathrm{mg} / \mathrm{L}, \mathrm{SS}: 356 \mathrm{mg} / \mathrm{L}$, TS: $436 \mathrm{mg} / \mathrm{L}$ and DS: $70 \mathrm{mg} / \mathrm{L}$. During the operation of MFCs, wastewater was undergoing some experiments to find out the characteristics of treated water. Following table listed some of the important determined results.

Table 1. Characterization of food processing wastewater

\begin{tabular}{|l|c|c|}
\hline \multicolumn{1}{|c|}{ Parameter } & Initial, $\mathrm{mg} / \mathrm{L}$ & Final, $\mathrm{mg} / \mathrm{L}$ \\
\hline Suspended Solids (SS) & 356 & 8 \\
\hline Dissolved Solids (DS) & 70 & 61 \\
\hline Total Solids (TS) & 436 & 69 \\
\hline \% COD Removal & \multicolumn{2}{|c|}{$77.71 \%$} \\
\hline
\end{tabular}

\section{Effect of Sludge Loading in MFC}

Effects of sludge loading in dual chamber MFC were analyzed by operating two cells having fixed amount of wastewater sample in each anode chamber. First cell was inoculated with $1 \mathrm{~g}$ of sludge and the other was operated without the sludge. $\mathrm{KMnO}_{4}$ was used as the oxidant in these cells and its concentration was kept constant at $200 \mathrm{mg} / \mathrm{L}$. This experiment was conducted in the closed circuit and the cells were connected with an external resistance of $1 \mathrm{k} \Omega$. From figures 2 and 3, it was clear that, MFC with sludge in the anode chamber has a great effect on current generation. Without sludge, the generation of current shows a decreasing trend. 


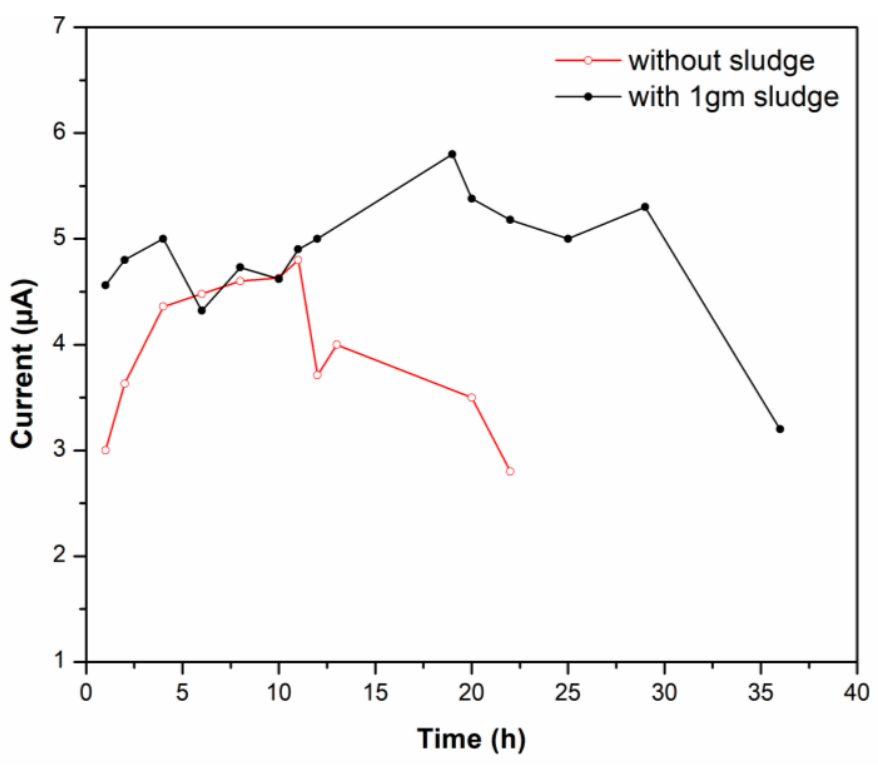

Figure 1. Comparison between MFCs running with sludge and without sludge

The graph (Figure 1) illustrates that, the cell using sludge at the anode chamber showed better current production and reached a peak value of $5.8 \mu \mathrm{A}$ at $19^{\text {th }}$ hour of operation. The current production in both cells increased initially and reached the decline phase after a bit unsteady performance. Sludge loading favors complex reactions, like hydrolysis, acidogenesis, electro-genesis and causes higher electricity generation undergone by micro-organisms [22]. Initial feed $\mathrm{pH}$ could be a cause of poor performance as unfavorable condition retards bacterial growth. As incorporation of sludge gives better performance, three more MFCs were operated with $3 \mathrm{~g}, 6 \mathrm{~g}$ and $9 \mathrm{~g}$ of sludge in the anode chambers, respectively (Figure 2). The experimental result reveals that increasing sludge loading at the anode chamber increases electricity generation. The cell operated by 9 g sludge provides better electricity production than the others and the cell operated without the sludge gives the least production of electricity.

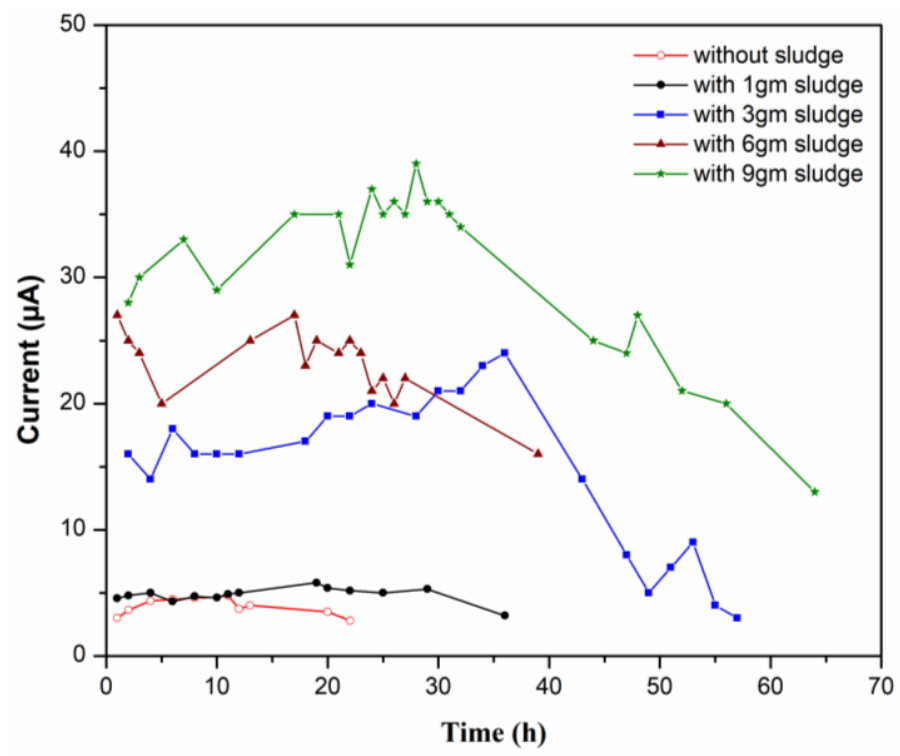

Figure 2. Effect of variable sludge loading in electricity generation 
Initial electricity generations were $28,27,20,4,3 \mu \mathrm{A}$ in $9,6,3,1,0$ g sludge containing cells, respectively. Increment of sludge loading causes increment of bacterial population, which favors electricity generation. This supports the result found by Behera et al. [22].

\section{Effect of Operating $\mathrm{pH}$}

Food processing industry wastewater is acidic in nature and neutralization of the wastewater is necessary for biological treatment. Higher acidity or alkalinity of wastewater affects both wastewater treatment efficiency and the environment inside the reactor [23]. The $\mathrm{pH}$ of wastewater needs to be maintained near neutral to protect microorganisms to favor biological treatment processes. For acidic or alkaline industrial wastewaters, the $\mathrm{pH}$ is corrected to near neutral by addition of suitable alkali or acid before biological treatment. The capacity of the anaerobic reactors to handle the loading rates depends on the feed $\mathrm{pH}$ and the alkalinity generating capability of the wastewater to counteract the changes in $\mathrm{pH}$. Therefore, in this study, the performance of MFC was evaluated under different anodic $\mathrm{pH}$ values.

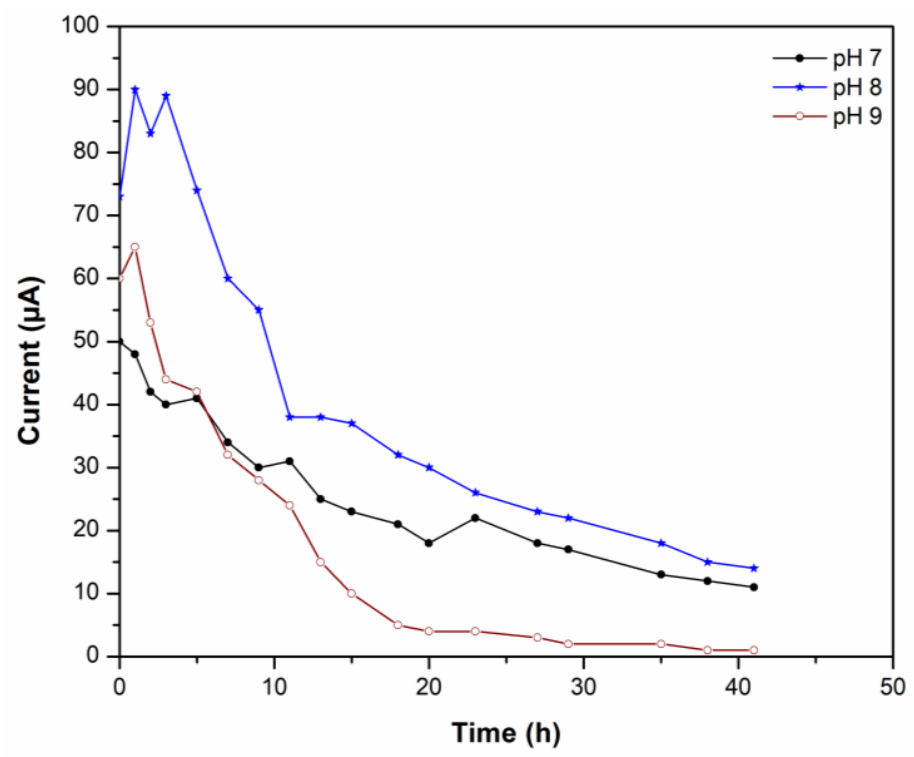

Figure 3. Effect of feed $\mathrm{pH}$ in electricity generation

From Figure 3, the experimental results clearly demonstrate that the MFC performance is dependent on the anodic $\mathrm{pH}$. The possible reason for higher current generation at $\mathrm{pH} 8.0$ might be attributed to the effective extracellular electron transfer at this $\mathrm{pH}$ microenvironment, where electrogenic bacterial growth was favored [24, 25]. As the feed $\mathrm{pH}$ was not constant in none of anode chamber, electricity also decreased sharply over time.

\section{Polarization and Power Curve}

The polarization curve characterizes the cell voltage as a function of current. In the microbial fuel cell, the current generation was depended on the size of the electrical load. In this regard, the polarization curve was used to explain the electrochemical efficiency with respect to the operating current. 


\section{Polarization and Power Curve for Variable Sludge Loading}

From Figure 4, it is observed that, when the current density of the cells increased, the cell potential decreased. It can be also seen that, potential energy increased when a higher amount of sludge was loaded. It can be explained as, because of the enhanced microbial population prevails in the presence of larger amount of sludge in the anode chamber. The maximum potential was recorded as $308 \mathrm{mV}$ from the cell containing $9 \mathrm{~g}$ of sludge. Power densities were also measured at variable external resistances. Current generation in different resistors was observed once the maximum voltage was attained, the maximum power density was recorded as $0.97 \mathrm{~mW} / \mathrm{m}^{2}$ at the current density of 5.6 $\mathrm{mA} / \mathrm{m}^{2}$ for the cell containing $9 \mathrm{~g}$ sludge in the anode chamber.

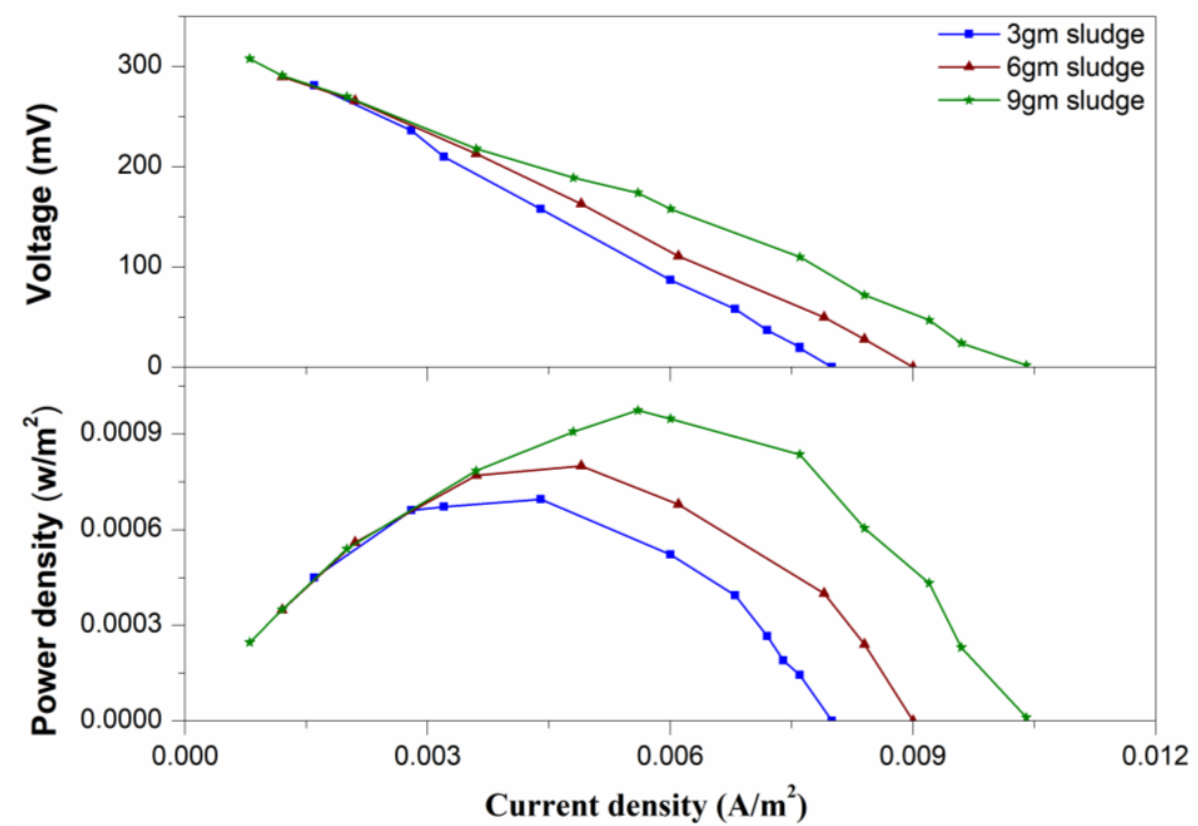

Figure 4. Power density curve and voltage behavior versus current density for three MFCs using variable sludge loading

At first, the power densities showed an incremental trend with increasing external resistance. After that, the power density started to decrease slowly with increasing resistance and current density. This typical fuel cell behavior was also reported by the researchers [26]. When a higher resistance was used, relatively less power density was observed. Relatively less voltage drop was observed at lower resistance indicating less potential drop. Voltage stabilization was comparatively rapid at higher resistances studied. Effective electron discharge observed at lower resistances might be the probable reason for further potential drop and slow stabilization of the voltage at lower resistances. Oxidation of substrates by microbes was more at lower resistance than at higher resistance, where microbes donated electrons to the anode as the electrons were discharged in a closed circuit compared the current generation potentiality of different substrate and source inoculums [2]. The power produced reported in our study is relatively moderate comparing to other researchers working with same substrate. Relatively lower power observed in this study might be due to the use of graphite electrode without any coating. 
Polarization \& Power Curve for different feed $\mathrm{pH}$

Current density and voltage generation with respect to the power density were observed at feed $\mathrm{pH} 8$ compared to others. The potential favor on biofilm generation at optimum $\mathrm{pH}$ is likely to be the reason [22]. The cell potential decreased with the increment of current density.

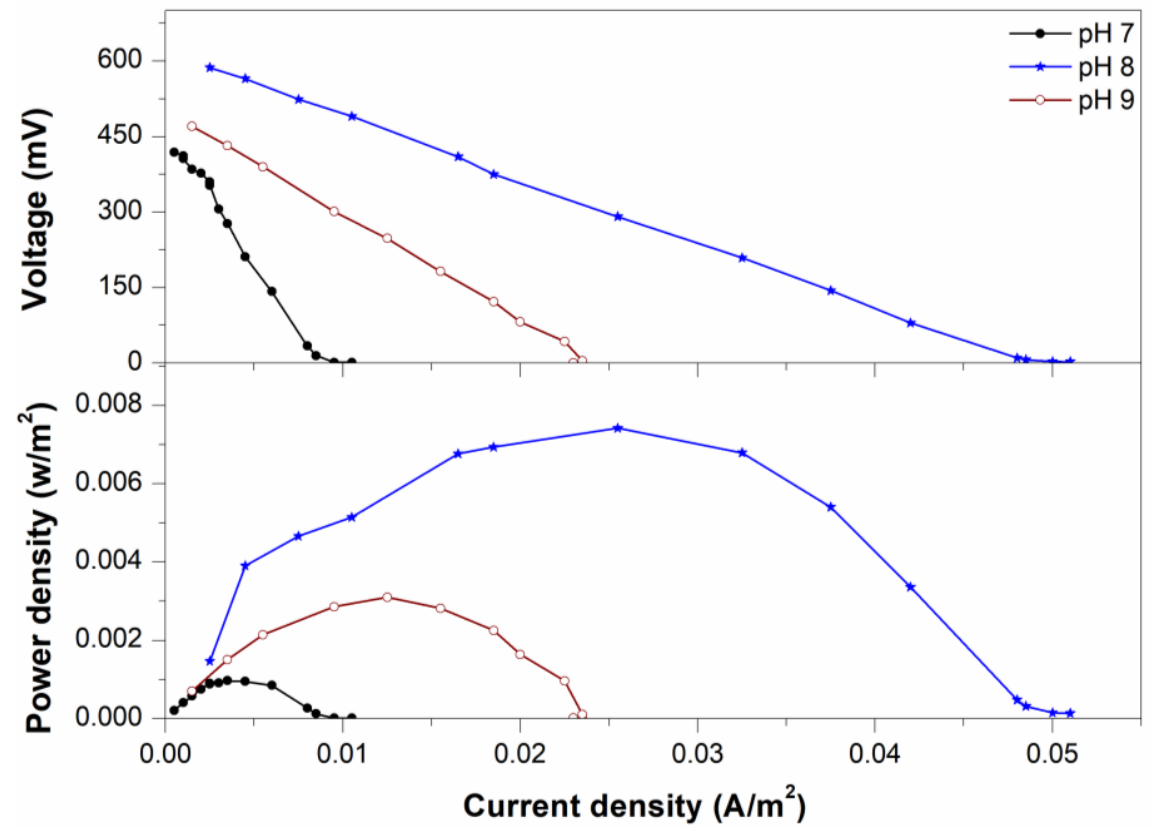

Figure 5. Power density curve and voltage behavior versus current density for three MFCs using different feed $\mathrm{pH}$.

It can be seen (Figure 6) that the maximum value of $587 \mathrm{mV}$ was achieved at current density $25 \mathrm{~mA} / \mathrm{m}^{2}$ for feed $\mathrm{pH} 8$. The utmost power density of $7.4 \mathrm{~mW} / \mathrm{m}^{2}$ was achieved with current density of $25 \mathrm{~mA} / \mathrm{m}^{2}$ at feed $\mathrm{pH} 8$.

\section{Removal of COD in Anode Chamber}

It has been reported that microorganisms can convert organic matters into electricity using MFCs while simultaneously accomplishing wastewater treatment [27]. Figure 6 shows the COD removal ratio of three MFCs containing 3, 6 and $9 \mathrm{~g}$ of sludge. In 64 hours of operation, the cells showed a COD removal efficiency of $30.73 \%, 44.56 \%$ and $55.13 \%$ for the cells containing 3,6 and $9 \mathrm{~g}$ of sludge in the anode chambers, respectively. 

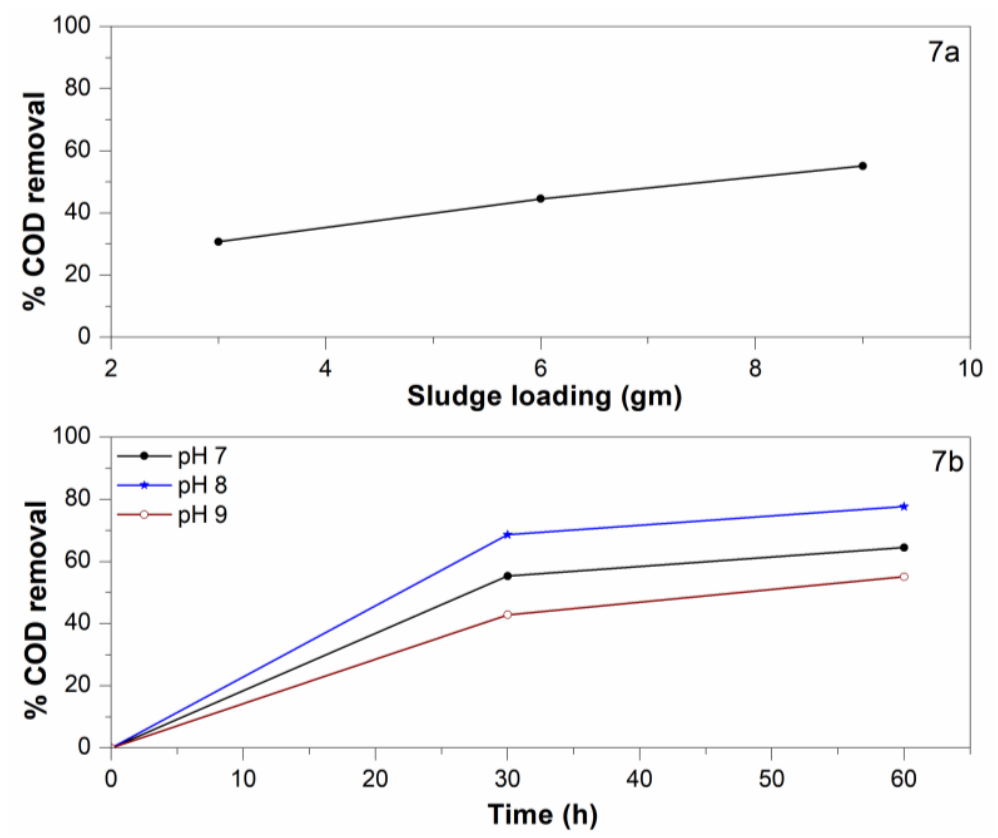

Figure 6. Percentage of COD removal of three MFCs having a) different sludge loading and b) feed $\mathrm{pH}$

The cells showed a COD removal efficiency of $64.51 \%, 77.71 \%$ and $55.54 \%$ for the cells containing having feed $\mathrm{pH} \mathrm{7,8}$ and 9 in the anode chambers over 52 hours of operation, respectively. So, the removal of COD is found to be higher for the cell which showed higher current production especially at the optimum $\mathrm{pH}$. This result is expected, because higher current production means higher utilization of the organic substrate in the anode chamber.

\section{Conclusion}

Dual chamber microbial fuel cell was fabricated and constructed with local available materials. Food processing industry wastewater was used as the substrate. Effect of sludge loading was investigated and found that, current generation of an MFC increased for a given concentration substrate with the increment of sludge. The effect of anode feed $\mathrm{pH}$ was explored. At the optimum $\mathrm{pH}$, a higher current was produced. Polarization and power curves were plotted for particular sets of MFCs. Due to the ohmic and external resistances, sharp drop in the voltage was observed with the increase of the current density. The removal of COD was found to be higher for the cell showing higher current density at optimum $\mathrm{pH}$. Though the power output was relatively low, 7.42 $\mathrm{mW} / \mathrm{m}^{2}$, it will be sufficient to run low-energy lighting or to recharge batteries for a host of devices such as cell phones. Therefore, it is necessary to expand this research work database by giving special attention to the digital data acquisition system, new types of electrode and membrane materials and scaling up of MFCs. So, the application of MFCs in Bangladesh can be effective to produce green electricity generation as well as the reuse of organic wastes to maintain the healthy and pollution free environment. 


\section{CONFLICTS OF INTEREST}

The authors declare that there is no conflict of interests regarding the publication of this paper.

\section{REFERENCES}

[1] K Hossain, A., and Badr, O. (2007). Prospects of renewable energy utilisation for electricity generation in Bangladesh. Renewable and Sustainable Energy Reviews, 11(8), 1617-1649.

[2] Pant, D., Bogaert, G. V., Diels, L., and Vanbroekhoven, K. (2010). A review for the substrate used in microbial fuel cell (MFCs) for sustainable energy production. Bioresource Technology, 101(6), 1533-1543.

[3] Logan, B. E., and Regan, J. M. (2006). Microbial fuel cells: Challenges and applications. Environ. Sci. Technol., 41, 5172-5180.

[4] Papaharalabos, G., Greenman, J., Melhuish, C., and Ieropoulos, I. (2015). A novel small scale Microbial Fuel Cell design for increased electricity generation and waste water treatment. International Journal of Hydrogen Energy, 40(11), 42634268.

[5] Latif, M. A., Rahman, M. H., and Ehasan, M. A. (2015). Agro-industrial development and sustainability in Bangladesh-A study. Int. J. Agril. Res. Innov. \& Tech., 5(2), 37-43.

[6] (2018).https://en.wikipedia.org/wiki/Food_industry_in_Bangladesh. [19/06/2018]

[7] Hussain, S. S., and Leishman, D. (2013). Gain Report on Food Processing Industries in Bangladesh. pp: 2-3.

[8] Khan, M. R., Amin, M. S. A., Rahman, M. T., Akbar, F., and Ferdaus, K. (2013). Factors affecting the performance of double chamber microbial fuel cell for simultaneous wastewater treatment and power generation. Polish Journal of Chemical Technology, 15(1), 7-11.

[9] Agency, E. E. (2001). Indicator: Biochemical oxygen demand in rivers European Environment Agency, Copenhagen, Denmark.

[10] Brião, V. B., and Tavares, C. R. G. (2007). Effluent generation by the dairy industry: preventive attitudes and opportunities. Brazilian Journal of Chemical Engineering, 24, 487-497.

[11] Ravinder, K., Lakhveer, S., W., Z. A., and I., H. F. (2018). Microbial fuel cell is emerging as a versatile technology: a review on its possible applications, challenges and strategies to improve the performances. International Journal of Energy Research, 42(2), 369-394.

[12] Cecconet, D., Molognoni, D., Callegari, A., and Capodaglio, A. G. (2018). Agrofood industry wastewater treatment with microbial fuel cells: Energetic recovery issues. International Journal of Hydrogen Energy, 43(1), 500-511.

[13] Luo, H., Xu, G., Lu, Y., Liu, G., Zhang, R., Li, X., Zheng, X., and Yu, M. (2017). Electricity generation in a microbial fuel cell using yogurt wastewater under alkaline conditions. RSC Advances, 7(52), 32826-32832.

[14] Logan, B. E., and Rittmaan, B. E. (2008). Opportunities for Renewable Bioenergy Using Microorganisms. Biotechnology and Bioengineering, 100(2), 203-212. 
[15] Oh, S. E., and Logan, B. E. (2005). Hydrogen and electricity production from a food processing wastewater using fermentation and microbial fuel cell technologies. Water Res., 39, 4673-4682.

[16] Du, Z., Li, H., and Gu, T. (2007). A state of the art review on microbial fuel cells: A promising technology for wastewater treatment and bioenergy. Biotechnology Advances, 25(5), 464-482.

[17] Amin, M. S. A., Haque, T., Tarannum, R., and Khan, M. R. (2014). Wastewater treatment and electricity generation by membrane less microbial fuel Int. J. Environmental Engineering, 6(3), 314-323.

[18] Mohan, S. V., Saravanan, R., Veer, S. R., Mohanakrishna, G., and Sarma, P. N. (2006). Bioelectricity production from wastewater treatment in dual chambered microbial fuel cell (MFC) using selectively enriched mixed microflora: Effect of catholyte. Bioresour. Technol., 99(3), 596-600.

[19] You, S., Zhao, Q., Zhang, J., Jiang, J., and Zhao, S. (2006). A microbial fuel cell using permanganate as the cathodic electron acceptor. J. Power Sour., 162, 14091415.

[20] Trinh, N. T., Park, J. H., and Kim, S. S. (2010). Generation behavior of electricity in a microbial fuel cell. Korean J. Chem. Eng., 27(2), 546-550.

[21] APHA (1998). Standard methods for the examination of water and wastewater. American Public Health Association, Washington DC, USA.

[22] Behera, M., and Ghangrekar, M. M. (2009). Performance of microbial fuel cell in response to change in sludge loading rate at different anodic feed $\mathrm{pH}$. Bioresource Technology, 100(21), 5114-5121.

[23] He, Z., Huang, Y., Manohar, A. K., and Mansfeld, F. (2008). Effect of electrolyte $\mathrm{pH}$ on the rate of the anodic and cathodic reactions in an air-cathode microbial fuel cell. Bioelectrochemistry, 74, 78-82.

[24] Jiang, J., Zhao, Q., Zhang, J., Zhang, G., and Lee, D.-J. (2009). Electricity generation from bio-treatment of sewage sludge with microbial fuel cell. Bioresource Technology, 100(23), 5808-5812.

[25] Gil, G.-C., Chang, I.-S., Kim, B. H., Kim, M., Jang, J.-K., Park, H. S., and Kim, H. J. (2003). Operational parameters affecting the performannce of a mediatorless microbial fuel cell. Biosensors and Bioelectronics, 18(4), 327-334.

[26] Venkata Mohan, S., Saravanan, R., Raghavulu, S. V., Mohanakrishna, G., and Sarma, P. N. (2008). Bioelectricity production from wastewater treatment in dual chambered microbial fuel cell (MFC) using selectively enriched mixed microflora: Effect of catholyte. Bioresource Technology, 99(3), 596-603.

[27] Liu, H., Cheng, S., and Logan, B. E. (2005). Production of Electricity from Acetate or Butyrate Using a Single-Chamber Microbial Fuel Cell. Environmental Science \& Technology, 39(2), 658-662.

Article copyright: (C) 2019 Mohammad Shaiful Alam Amin, Musabbir Jahan Talukder, Rajarshi Roy Raju, Maksudur R. Khan. This is an open access article distributed under the terms of the Creative Commons Attribution 4.0 International License, which permits unrestricted use and distribution provided the original author and source are credited.

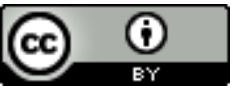

